\title{
Ammonifex thiophilus sp. nov., a hyperthermophilic anaerobic bacterium from a Kamchatka hot spring
}

Correspondence Margarita Miroshnichenko alfamirr@mail.ru

\author{
Margarita L. Miroshnichenko, ${ }^{1}$ Tatyana P. Tourova, ${ }^{1}$ Tatyana V. Kolganova, ${ }^{2}$ \\ Nadezhda A. Kostrikina, ${ }^{1}$ Nikolay Chernych ${ }^{1}$ \\ and Elizaveta A. Bonch-Osmolovskaya ${ }^{1}$
}

\author{
${ }^{1}$ Winogradsky Institute of Microbiology, Russian Academy of Sciences, Prospect 60-Letiya \\ Oktyabrya 7/2, 117312 Moscow, Russia \\ ${ }^{2}$ Bioengineering Center, Russian Academy of Sciences, Prospect 60-Letiya Oktyabrya 7/1, \\ 117312 Moscow, Russia
}

Geothermal areas in the Uzon Caldera, Kamchatka, have created a diverse array of extreme microbial habitats. Over the years, many novel anaerobic thermophilic or hyperthermophilic archaea and bacteria have been isolated from this unique ecosystem. The majority of these isolates are chemoorganoheterotrophs utilizing complex proteinaceous substrates (Bonch-Osmolovskaya et al., 1988, 1990, 1991; Zavarzina et al., 2000, 2002; Perevalova et al., 2005; Kublanov et al., 2007). However, hot springs in the Uzon Caldera are rich in $\mathrm{CO}_{2}$ with an admixture of $\mathrm{CH}_{4}, \mathrm{~S}, \mathrm{CO}$ and $\mathrm{H}_{2}$, which may strongly support chemolithotrophic metabolism. Radioisotopic experiments aimed at determining the rates of the main microbial processes (lithotrophic and acetoclastic methanogenesis, acetate oxidation and $\mathrm{CO}_{2}$ assimilation and sulfate reduction) have also indicated the presence of lithotrophic prokaryotes in the Uzon Caldera (BonchOsmolovskaya et al., 1999). However, to date only few thermophilic anaerobes capable of chemolithoautotrophic growth have been isolated from the Uzon Caldera hot springs. These are moderately thermophilic, sulfur-reducing bacteria of the genus Desulfurella (Bonch-Osmolovskaya

The GenBank/EMBL/DDBJ accession number for the 16S rRNA gene sequence of strain $\mathrm{SR}^{\top}$ is EF554597. et al., 1990; Miroshnichenko et al., 1998). In this paper, we describe novel extremely thermophilic, anaerobic, facultatively lithoautotrophic bacteria inhabiting one of the hottest springs of the Uzon Caldera.

A sample of sediments mixed with water was collected from Treshchinnyi Spring, East Thermal Field. The temperature and $\mathrm{pH}$ at the sampling site were $80{ }^{\circ} \mathrm{C}$ and 6.3 , respectively. The evolving gases consisted of $\mathrm{CO}_{2}, \mathrm{~N}_{2}, \mathrm{H}_{2} \mathrm{~S}, \mathrm{CH}_{4}$ and $\mathrm{H}_{2}$ (N. V. Pimenov, personal communication).

For the enrichment culture, anaerobically prepared modified Pfennig medium (Miroshnichenko et al., 1998) was used supplemented with $1 \mathrm{mg} \mathrm{l}^{-1}$ resazurin (Sigma), $1 \mathrm{ml} \mathrm{l}^{-1}$ trace element solution (Pfennig \& Lippert, 1966) and $1 \mathrm{ml} \mathrm{l}^{-1}$ vitamin solution (Wolin et al., 1963). After boiling, the medium was cooled under $\mathrm{CO}_{2}$ and supplemented with $2 \mathrm{~g} \mathrm{l}^{-1} \mathrm{Na}_{2} \mathrm{~S}_{2} \mathrm{O}_{3}, 1.5 \mathrm{~g} \mathrm{l}^{-1} \mathrm{NaHCO}_{3}$ and $0.5 \mathrm{~g} \mathrm{l}^{-1} \mathrm{Na}_{2} \mathrm{~S} .9 \mathrm{H}_{2} \mathrm{O}$. To adjust the $\mathrm{pH}$ of the medium to $6.8,10 \% \mathrm{NaOH}$ was added at a concentration of $5 \mathrm{ml} \mathrm{l}^{-1}$. The medium was dispensed as $5 \mathrm{ml}$ samples into $20 \mathrm{ml}$ Balch tubes; the headspace was filled with $100 \% \mathrm{H}_{2}$.

After 5 days incubation at $82{ }^{\circ} \mathrm{C}$, the growth of rod-shaped cells was observed. The culture was purified using the dilution-to-extinction technique and the resulting isolate 
was designated as strain $\mathrm{SR}^{\mathrm{T}}$. Electron microscopy (BonchOsmolovskaya et al., 1990) indicated that cells of the novel isolate had peritrichous flagellation and a cell wall typical of Gram-positive bacteria (Fig. 1). The cells were 0.6$0.7 \mu \mathrm{m}$ wide, 3-6 $\mu \mathrm{m}$ long and appeared singly or in pairs. Strain $\mathrm{SR}^{\mathrm{T}}$ formed round terminal endospores after long (5-7 days) incubation at $75{ }^{\circ} \mathrm{C}$. The percentage of sporulated cells, though, was less than $1-2 \%$.

After demonstrating that strain $\mathrm{SR}^{\mathrm{T}}$ grew well with formate $(10 \mathrm{mM})$ and thiosulfate $(10 \mathrm{mM})$, this donor-acceptor pair was chosen for growth experiments carried out with $\mathrm{CO}_{2}(100 \%)$ filling the head space of the tubes (see results in Table 1).

Isolate $\mathrm{SR}^{\mathrm{T}}$ grew only on the prereduced medium over a temperature range from 60 to $82{ }^{\circ} \mathrm{C}$ (optimally at $75{ }^{\circ} \mathrm{C}$ ) and over a $\mathrm{pH}$ range from 6.0 to 7.5 (optimally at $\mathrm{pH} 6.8-$ 7.0). In the presence of thiosulfate under optimized conditions, the following compounds did not support the growth of strain $\mathrm{SR}^{\mathrm{T}}$ : acetate, ethanol, propionate, methanol, glucose, fructose, pyruvate, fumarate, malate, succinate or lactate (all at $10 \mathrm{mM}$ ) and yeast extract, starch or peptone (at $10 \mathrm{~g} \mathrm{l}^{-1}$ ). These data suggested that molecular hydrogen and formate were the only energy substrates used by strain $\mathrm{SR}^{\mathrm{T}}$. The electron acceptors tested for their ability to support the growth of strain $\mathrm{SR}^{\mathrm{T}}$ were selected from the following: $\mathrm{S}^{0}\left(10 \mathrm{~g} \mathrm{l}^{-1}\right), \mathrm{NO}_{3}^{-}(10 \mathrm{mM})$, $\mathrm{SO}_{4}^{2-}(10 \mathrm{mM}), \mathrm{SO}_{3}^{2-}(2 \mathrm{mM})$ and $\mathrm{NO}_{2}^{-}(10 \mathrm{mM})$. At the optimum temperature and $\mathrm{pH}$ values, the best growth for strain $\mathrm{SR}^{\mathrm{T}}\left(8.3 \times 10^{7}\right.$ cells $\left.\mathrm{ml}^{-1}\right)$ was observed with formate
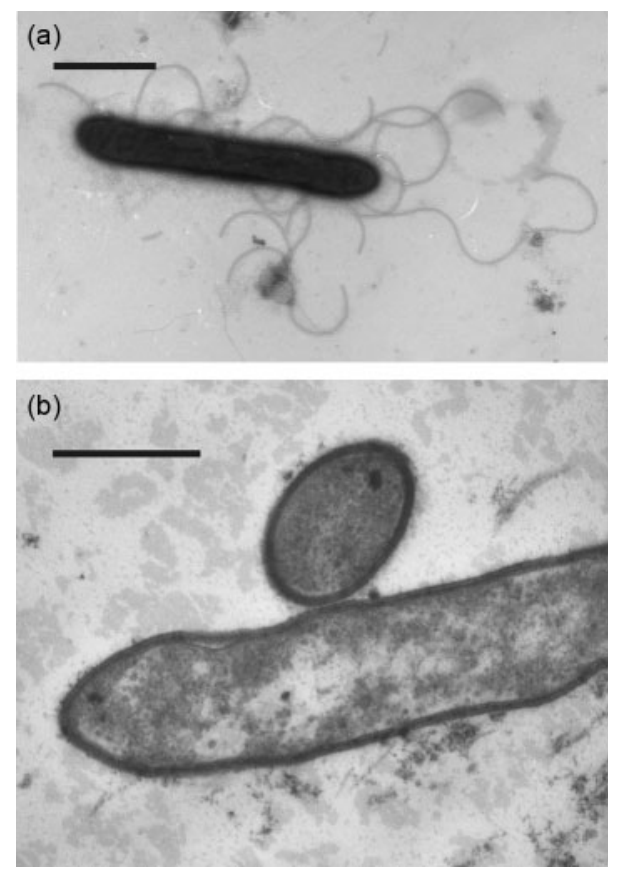

Fig. 1. Electron micrographs of cells of strain $S R^{\top}$. Negative staining of whole cell (a) and thin section (b). Bars, $0.5 \mu \mathrm{m}$. and thiosulfate. The final cell density on medium with formate and $\mathrm{S}^{0}$ or $\mathrm{SO}_{4}^{2-}$ as electron acceptors was $7.5 \times 10^{6}$ cells $\mathrm{ml}^{-1}$. The final end product of anaerobic respiration (Trüper \& Schlegel, 1964) was $\mathrm{H}_{2} \mathrm{~S}$.

DNA was prepared as described by Marmur (1961). The $\mathrm{G}+\mathrm{C}$ content of the DNA was determined by melting point analysis (Marmur \& Doty, 1962) using Escherichia coli K-12 DNA as a reference. The DNA G $+C$ content for strain $\mathrm{SR}^{\mathrm{T}}$ was $56.2 \mathrm{~mol} \%$. For amplification and sequencing of the $16 \mathrm{~S}$ rRNA genes, DNA was obtained by standard phenol/ chloroform extraction. The $16 \mathrm{~S}$ rRNA genes were selectively amplified using 5'-AGAGTTGATCCTGGCTCAG-3' and 5'TACGGTTACCTTGTTACGACTT- $3^{\prime}$ as the forward and reverse primers, respectively. The PCR products were purified using the Wizard PCR Prep kit (Promega) according to the manufacturer's instructions. Sequencing was performed using Big Dye Terminator v.3.1 sequencing reaction kit and an ABI 3730 DNA automatic sequencer (Applied Biosystems). Preliminary phylogenetic analysis of the new sequences was conducted using the NCBI BLAST server (http:// www.ncbi.nlm.nih.gov/BLAST/). The nucleotide sequences were aligned with sequences from the GenBank using CLUSTAL w. The phylogenetic tree was reconstructed using the neighbour-joining algorithm as implemented in the TREECONW software package (Van de Peer \& De Wachter, 1994). A comparison of the almost complete 16S rRNA gene sequence (1536 nucleotides) of isolate $\mathrm{SR}^{\mathrm{T}}$ with the database suggested that the novel strain belonged to the Gram-positive bacteria of the Moorella group and was most related to the genus Ammonifex, with similarity as high as $96.4 \%$ (Fig. 2).

The new isolate was compared with Ammonifex degensii DSM $10501^{\mathrm{T}}$, the only recognized member of this genus and isolated from an Indonesian volcanic hot spring (Huber et al., 1996). Both organisms had rod-shaped cells with a Gram-positive type cell wall. Although A. degensii has been characterized as a Gram-negative bacterium (Huber et al., 1996), no outer membrane characteristic for this type of cells has been documented. Both strains were thermophilic obligate anaerobes that were capable of growing autotrophically by the oxidation of $\mathrm{H}_{2}$ or formate, using $\mathrm{CO}_{2}$ as the carbon source. Both strains were able to grow weakly by the reduction of sulfate or sulfur. The DNA $\mathrm{G}+\mathrm{C}$ contents of $A$. degensii and strain $\mathrm{SR}^{\mathrm{T}}$ were very similar at 54 and $56.2 \mathrm{~mol} \%$, respectively. However, comparisons of metabolic and physiological characteristics of the two strains revealed a number of significant differences (Table 1).

It was found that $A$. degensii DSM $10501^{\mathrm{T}}$ and strain $\mathrm{SR}^{\mathrm{T}}$ used different sets of electron acceptors. Strain $\mathrm{SR}^{\mathrm{T}}$ reduced thiosulfate as the preferential electron acceptor, but did not use nitrate. A. degensii reduced nitrate to ammonium (this trait is reflected in the name of the genus), but was not able to grow with thiosulfate as the electron acceptor. Strain $\mathrm{SR}^{\mathrm{T}}$ was not capable of fermentative growth, whereas $A$. degensii grew by pyruvate fermentation. In addition, the growth rate of strain $\mathrm{SR}^{\mathrm{T}}$ was higher than that of $A$. degensii 
Table 1. Comparative characteristics of strain $\mathrm{SR}^{\top}$ and Ammonifex degensii DSM $10501^{\top}$

Data for A. degensii are from Huber et al. (1996). +, Positive; -, negative.

\begin{tabular}{|lcc|}
\hline Characteristic & Strain $\mathbf{S R}^{\mathbf{T}}$ & A. degensii \\
\hline Cell shape & Rods $(0.6-0.7 \times 3-6 \mu \mathrm{m})$ & $\begin{array}{c}\text { Rods }(0.6 \times 2-4.5 \mu \mathrm{m}) \\
\text { Gram-negative }\end{array}$ \\
Cell wall & Gram-positive & Terminal and lateral \\
Flagellation & Peritrichous & - \\
Ability to form spores & + & - \\
Electron acceptors used: & + & + \\
Thiosulfate & - & + \\
Nitrate & - & $57-77$ \\
Fermentative growth with & & 70 \\
pyruvate & $60-82$ & 54 \\
Temperature for growth $\left({ }^{\circ} \mathrm{C}\right)$ & 75 & \\
Range & 56.2 & \\
Optimum & & \\
DNA G $+\mathrm{C}$ content & & \\
(mol\%) & & \\
\hline
\end{tabular}

${ }^{\star}$ However, no outer membrane has been documented.

and its temperature range and optima were shifted to higher values when compared with those of $A$. degensii.

While both organisms were isolated from terrestrial hot springs, recent environmental $16 \mathrm{~S}$ rRNA gene sequence analyses have shown that the deep-subsurface environment is dominated by representatives of the so-called Ammonifex group. An abundant group of bacterial clones ( $83 \%$ clonal frequency) related to $A$. degensii as the closest relative (91\% gene sequence similarity) was found in ridge flank oceanic crusts (Nakagawa et al., 2006). Based on the metabolic capacities of $A$. degensii, speculations have been made on the ecological function of these organisms as regards the production of ammonium from nitrate (Cowen et al., 2003). Although strain $\mathrm{SR}^{\mathrm{T}}$ belongs to the same group of organisms, it was not able to reduce nitrate indicating that this group of organisms could accomplish other functions in microbial communities.

Isolate $\mathrm{SR}^{\mathrm{T}}$ differed from $A$. degensii in $16 \mathrm{~S}$ rRNA gene sequence $(96.4 \%$ similarity) and in some important phenotypic features. On the basis of these differences, it

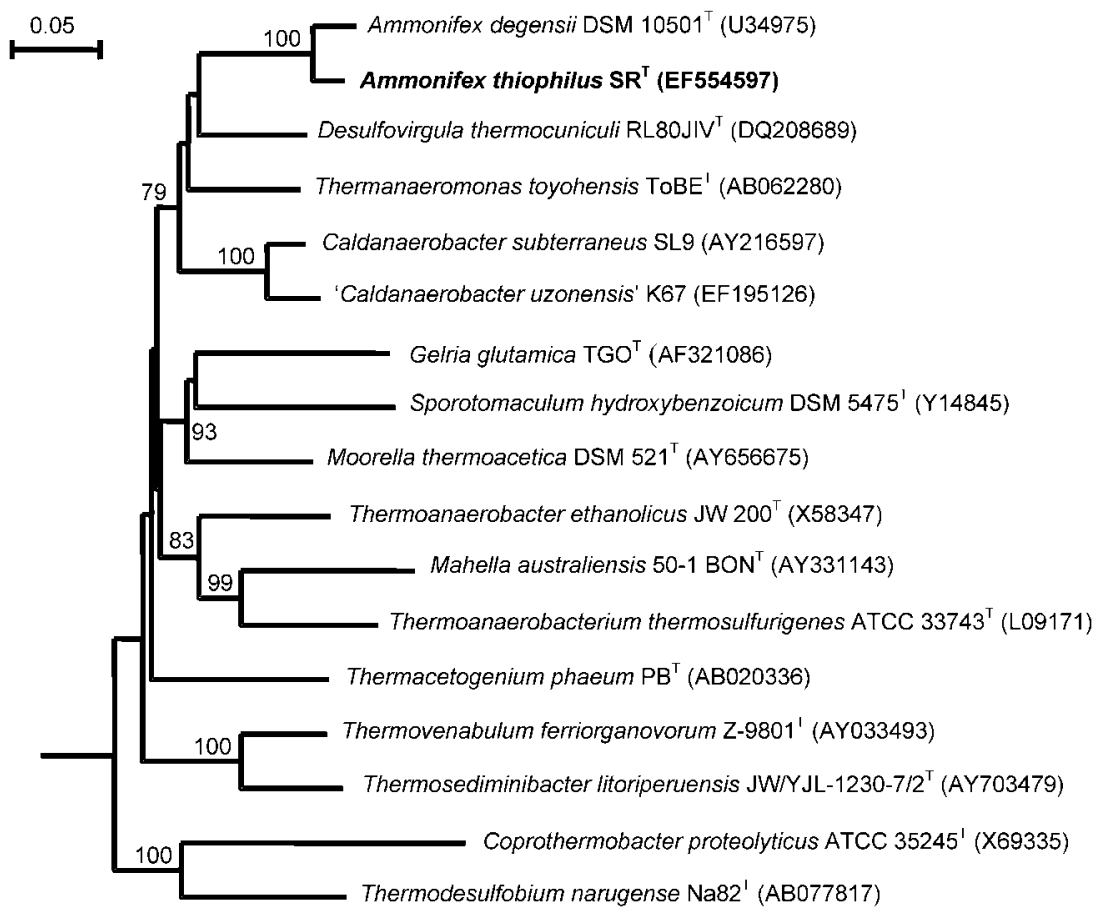

Fig. 2. The position of strain $S R^{\top}$ of the order Thermoanaerobacteriales in a phylogenetic tree constructed by a comparison of the nucleotide sequence of the 16S rRNA genes. Escherichia coli was used as outgroup. Tree topology and evolutionary distances are given by the neighbour-joining method with Jukes \& Cantor distances. Bootstrap values (expressed as percentage of 100 replications) are shown as branch points; values $>70$ were considered significant. Bar, 5 nucleotide substitutions per 100 nucleotides. 
is suggested that the new strain is assigned as the type strain of a novel species, for which the name Ammonifex thiophilus sp. nov. is proposed.

\section{Emended description of the genus Ammonifex}

Ammonifex [Am.mo.ni.fex. L. neut. n. sal ammoniacum salt of Ammon $\left(\mathrm{NH}_{4} \mathrm{Cl}\right)$; L. v. facere to make; N.L. masc. n. Ammonifex the ammonium-maker].

The description is based on that given by Huber et al. (1996). Cells are Gram-positive rods. Some species form spores. Facultatively chemolithoautotrophic. Able to oxidize hydrogen and formate, reducing nitrate to ammonium, or, alternatively, reducing thiosulfate, sulfate or elemental sulfur to hydrogen sulfide. The DNA $\mathrm{G}+\mathrm{C}$ content is in the range $54-56 \mathrm{~mol} \%$.

\section{Description of Ammonifex thiophilus sp. nov.}

Ammonifex thiophilus (thi.o' phi.lus. Gr. n. thion sulfur; Gr. adj. phylos loving; N.L. neut. adj. thiophilus sulfur-loving).

Cells are peritrichously flagellated, non-motile rods of 0.6$0.7 \mu \mathrm{m}$ in diameter and 3-6 $\mu \mathrm{m}$ in length. Cell wall is of the Gram-positive type. Spore-forming. Obligately anaerobic. Growth occurs between 60 and $82{ }^{\circ} \mathrm{C}$, with an optimum at $75{ }^{\circ} \mathrm{C}$. The $\mathrm{pH}$ range for growth is $6.0-7.5$, with an optimum at 6.8-7.0. Facultatively chemolithoautotrophic. Hydrogen- and formate-oxidizing. Reduces thiosulfate, sulfate or elemental sulfur to $\mathrm{H}_{2} \mathrm{~S}$.

The type strain, $\mathrm{SR}^{\mathrm{T}}\left(=\mathrm{DSM} 19636^{\mathrm{T}}=\mathrm{VKM} \mathrm{B}-2461^{\mathrm{T}}\right.$ ), was isolated from Treshchinnyi hot spring, Uzon Caldera, Kamchatka, Russia. The DNA G + C content of the type strain is $56.2 \mathrm{~mol} \%$.

\section{Acknowledgements}

This work was supported by RFBR grant No 06-04-49045 and the Programs of RAS 'Molecular and Cell Biology' and 'Origin and evolution of biosphere'.

\section{References}

Bonch-Osmolovskaya, E. A., Slesarev, A. I., Miroshnichenko, M. L., Svetlichnaya, T. P. \& Alekseev, V. A. (1988). Characteristics of Desulfurococcus amylolyticus sp. nov, a new extreme-thermophilic archaebacterium from hot volcanic vents of Kamchatka and Kunashir Island. Microbiology (English translation of Microbiologiia) 57, 78-85.

Bonch-Osmolovskaya, E. A., Sokolova, T. G., Kostrikina, N. A. \& Zavarzin, G. A. (1990). Desulfurella acetivorans gen. nov. and sp. nov. - a new thermophilic sulfur-reducing eubacterium. Arch Microbiol 153, 151-155.

Bonch-Osmolovskaya, E. A., Miroshnichenko, M. L., Kostrikina, N. A., Chernych, N. A. \& Zavarzin, G. A. (1991). Thermoproteus uzoniensis sp. nov., a new extremely thermophilic archaebacterium from Kamchatka continental hot springs. Arch Microbiol 154, 556-559.
Bonch-Osmolovskaya, E. A., Miroshnichenko, M. L., Slobodkin, A. I., Sokolova, T. G., Karpov, G. A., Kostrikina, N. A., Zavarzina, D. G., Prokofeva, M. I., Rusanov, I. I. \& Pimenov, N. V. (1999). Biodiversity of anaerobic lithotrophic prokaryotes in terrestrial hot springs of Kamchatka. Microbiology (English translation of Microbiologiia) 68, 398-406.

Cowen, J. P., Giovannoni, S. J., Kenig, F., Johnson, H. P., Butterfield, D., Rappe, M. S., Hutnak, M. \& Lam, P. (2003). Fluids from aging ocean crust that support microbial life. Science 299, 120-123.

Huber, R., Rossnagel, P., Woese, C. R., Rachel, R., Langworthy, T. A. \& Stetter, K. O. (1996). Formation of ammonium from nitrate during chemolithoautotrophic growth of the extremely thermophilic bacterium Ammonifex degensii gen. nov., sp. nov. Syst Appl Microbiol 19, 40-49.

Kublanov, I. V., Prokofeva, N. A., Kolganova, T. V., Tourova, T. P., Wiegel, J. \& Bonch-Osmolovskaya, E. A. (2007). Thermoanaerobacterium aciditolerans sp. nov., a moderate thermoacidophile from a Kamchatka hot spring. Int J Syst Evol Microbiol 57, 260-264.

Marmur, J. (1961). A procedure for the isolation of deoxyribonucleic acid from microorganisms. J Mol Biol 3, 208-218.

Marmur, J. \& Doty, P. (1962). Determination of the base composition of deoxyribonucleic acid from its thermal denaturation temperature. $J$ Mol Biol 5, 109-118.

Miroshnichenko, M. L., Rainey, F. A., Hippe, H., Chernyh, N. A., Kostrikina, N. A. \& Bonch-Osmolovskaya, E. A. (1998). Desulfurella kamchatkensis and Desulfurella propionica sp. nov., new sulfurrespiring thermophilic bacteria from Kamchatka thermal environments. Int J Syst Bacteriol 48, 475-479.

Nakagawa, S., Inagaki, F., Suzuki, Y, Steinsbu, B. O., Lever, M. A., Takai, K., Engelen, B., Sako, Y., Wheat, C. G. \& Horikoshi, K. (2006). Microbial community in black rust exposed to hot ridge flank crustal fluids. Appl Environ Microbiol 72, 6789-6799.

Perevalova, A. A., Svetlichny, V. A., Kublanov, I. V., Chernyh, N. A., Kostrikina, N. A., Tourova, T. P., Kuznetsov, B. B. \& BonchOsmolovskaya, E. A. (2005). Desulfurococcus fermentans sp. nov., a novel hyperthermophilic archaeon from a Kamchatka hot spring, and emended description of the genus Desulfurococcus. Int J Syst Evol Microbiol 55, 995-999.

Pfennig, N. \& Lippert, K. D. (1966). Über das vitamin $B_{12}$-bedürfnis phototropher schwefelbacterien. Arch Microbiol 55, 245-256.

Trüper, H. G. \& Schlegel, H. G. (1964). Sulfur metabolism in Thiorhodaceae. I. Quantitative measurements on growing cells of Chromatium okenii. Antonie van Leeuwenhoek 30, 225-238.

Van de Peer, Y. \& De Wachter, R. (1994). TREECON for Windows: a software package for the construction and drawing of evolutionary trees for the Microsoft Windows environment. Comput Appl Biosci 10, 569-570.

Wolin, E. A., Wolin, M. J. \& Wolfe, R. S. (1963). Formation of methane by bacterial extracts. J Biol Chem 238, 2882-2886.

Zavarzina, D. G., Zhilina, T. N., Tourova, T. P., Kuznetsov, B. B., Kostrikina, N. A. \& Bonch-Osmolovskaya, E. A. (2000). Thermanaerovibrio velox sp. nov., a new anaerobic, thermophilic, organotrophic bacterium that reduces elemental sulfur, and emended description of the genus Thermanaerovibrio. Int J Syst Evol Microbiol 50, 1287-1295.

Zavarzina, D. G., Zhilina, T. N., Tourova, T. P., Kuznetcsov, B. B., Bonch-Osmolovskaya, E. A. \& Slobodkin, A. I. (2002). Thermovenabulum ferriorganovorum gen. nov., sp. nov., a novel thermophilic, anaerobic, endospore-forming bacterium. Int J Syst Evol Microbiol 52, 1737-1743. 